\title{
Fabula és história határán Két festői történet a XVI. század Magyarországáról
}

The paper discusses two anecdotes concerning the Hungarian court. The first anecdote is transmitted by Le Vite of Giorgio Vasari on Visino, a Florentine painter, and his adventure in the court of Louis II. The big-mouth Florentine almost lost his life because the Hungarian aristocrats misunderstood his communicating of cultural preferences for Tuscany in comaprison to Buda court. The other text is a short narrative taken from the Le Sei Giornate of Sebastiano Erizzo. Erizzo's story tells about King John Szapolyai and one of his servants who stole a precious ring from his master. The servant accuses a painter of the sin and almost makes him killed for something the painter did not commit. The King, conscious about his servant's deed frees the painter and punishes the servant by sending him away from his service and giving him the same ring the servant risked his own position and another person's life for. My analysis discusses the possible historical and cultural background of the two stories. It also calls attention to the psychological effects they may have caused in their contemporary readers and the different reading strategies we approach them after the Enlightment of European culture. ${ }^{1}$

A jelen tanulmány két olyan itáliai eredetű rövid elbeszélésre koncentrál, amelyek valószínü történeti hátterét a XVI. századi Magyarországon kell keresnünk, s amelyek itáliai müvészek sorsát tárgyazzák. Ez a két elbeszélés

1 A szerző az MTA BTK Irodalomtudományi Intézet tudományos segédmunkatársa, a publikáció elkészítését az MTA-SZTE Antikvitás és reneszánsz: források és recepció Kutatócsoport (TK2016-126) támogatta. 
is több olyan, a Magyar Királyság lakóira vonatkozó elképzelést tükröz, amelyek több más olasz vagy latin nyelvü, az Appenini-félszigetről származó történetben is megjelentek. A Visino nevü firenzei festőről szóló anekdota tudomásom szerint e tanulmány lapjain olvasható először magyarul, míg a másik novella egy évszázad után kap újabb magyar fordítást.

Első történetünk a magyar királyi udvar légköréről, s egy oda érkező olasz festőről, Mariotto Albertinelli tanítványáról, a firenzei Visinóról szóló anekdota, amely Giorgio Vasarinak röviden csak Le vite címen híressé vált életrajzi gyűjteményében maradt fenn. Fógel József ${ }^{2}$ szerint az eset II. Lajos király udvarában játszódott le:

[...] ugyanőt néhány firenzei kereskedő Magyarországra vitte, ${ }^{3}$ ahol sok múvet készített, és eléggé elismert lett. De kis híja volt, hogy ez a szerencsétlen ember pórul járjon, aki, mivel természetéből adódóan szabad és fesztelen volt, nem bírta elviselni bizonyos okvetetlenkedő magyarok kellemetlenkedését, akik egész nap azzal tömték a fejét, hogy annak az országnak a dolgait dicsérték, mintha semmi másban nem lehetne jót és boldogságot találni, csak az ő kályháikban, meg az evésben és az ivásban, és mintha más előkelőség és nemesség nem lenne másutt, csak az ő királyukban és udvarában, és mintha minden más csak sár lenne; és neki úgy tünt, mint ahogyan úgy is van, hogy Itália dolgaiban másféle jóság, finomság és szépség rejtőzik, és egyszer, kifárasztva az efféle hülyeségeiktől, amikor véletlenségből egy kissé vidám volt, kiszaladt a száján, hogy szerinte többet ér egy flaska trevisói bor és egy mazsolás perec, mint ahány király és királyné abban az országban valaha is volt. És ha nem úgy esett volna, hogy a dolog egy úriember és a világ dolgaiban jártas püspök kezébe kerül (aki az egészet elmesélte), aki visszafogott volt és a dolgot tréfára tudta és akarta is fordítani, akkor Visino megtanult volna kesztyübe dudálni, mert azok az állati magyarok, nem értvén a szavait, és azt gondolván, hogy ő valami nagy dolgot mondott, mintha legalábbis el akarta volna venni a királyuk és az országuk életét, a népharagnak kitéve, a menekülés lehetősége nélkül keresztre akarták feszíteni. De az a jószándékú püspök kihúzta a bajból, és megbecsülvén, hogy mennyit ért ennek a tehetséges embernek az

\footnotetext{
2 FóGEL József, II. Lajos udvartartása 1516-1526, Bp., MTA, 1917, 84.

3 A fordítás alapjául a következő kiadás szolgált: Giorgio VASARI, Le vite de' più eccellenti pittori, scultori e architettori, Firenze, Adriano Salani Editore, 1930, III, 501-502.
} 
erénye, jóra fordítva a dolgot, visszahelyezte őt a király kegyébe, és Visino megértve ezt, megnyugodott, $\mathrm{s}$ aztán végül abban az országban eléggé megbecsülték és megjutalmazták az erényét. De a kalandja nem tartott sokáig, mert nem volt képes elviselni a kályhákat, sem pedig azt a hideg levegőt, amely ellenkezett a testfelépítésével; rövid úton véget ért, de életben maradt az iránta érzett hála és jó híre azokban, akik életében ismerték őt, és akik lassacskán megismerték a munkáit.

A festményeit körülbelül 1512-ben készítette. ${ }^{4}$

A Visinóról ${ }^{5}$ szóló anekdotában több visszatérő motívumot is találunk: például azt, az olaszok közt a magyarokról máig is élő sztereotípiát, hogy a magyarok sokat isznak és igen füszeresen esznek. Hasonló előítélet fogalmazódik meg Poggio Bracciolini egyik faceziájában, ${ }^{6}$ ahol egy firenzei pap a Magyarországon tapasztalt szokásokból vonja le azt a (természetesen téves) következtetést, hogy az embereknek a másnaposságtól véreres a szemük. A másik, a két nép között máig is élő konfliktusforrás a fütés kérdése: Visino valószínúleg nem bírta azokból a szép majolikacserepes kályhákból áradó meleget, amelyek Mátyás építkezései nyomán díszítették a palotáit, és amelyeknek maradványait még a XX. századi feltárások is

${ }^{4}$ A hivatkozott kiadás szerint az 1512-es dátum talán Albertinelli festményeire vonatkozik, nem Visino magyarországi müködésére.

5 Visino neve nem szerepel MiKó Árpád, A reneszánsz Magyarországon, Bp., Corvina, 2009 című kötetében, bár a munka inkább a nagy tendenciák összefoglalása, mint részletes almanach, s nem vezeti rekonstrukciós szándék a csak írásos emlékekből ismert alkotók és munkáik listázására.

6 Poggio BRACCIOLINI, Elméncségek - Reneszánsz egypercesek, ford. CSEHY Zoltán, Pozsony, Kalligram, 2009, 162. nr. CXLV. Egy firenzei papról, aki Magyarországon járt: „Magyarországon az a szokás járja, hogy miután a szentmise véget ér, azok, akiknek szembetegségük van, közelebb jönnek az oltárhoz, a pap pedig a kehelyből szentelt vízzel hinti meg a szemüket. Mindeközben a szentírás szavait idézi, s gyógyulásért imádkozik. Egyszer Filippóval, akit „a Spanyolként" ismernek, Magyarországra jött egy firenzei pap is. Egyszer Zsigmond király jelenlétében misét mondott, s elébe járultak a szembetegek, hogy a szokásnak megfelelően meghintse a szemüket. A pap azt hitte, hogy a mértéktelen ivás és másnaposság miatt látszik gyulladtnak a szemük, fogta hát a kelyhet és (ahogy ezt látta) meghintette az előtte állókat és olaszul így fakadt ki: „Andatevene che siate morti a ghiado!” (Takarodjatok innen, megérdemlitek, hogy kard által vesszetek!) A király és császár, aki értette a szavait, nem tudta megállni, hogy ne nevessen. Másnap az ebédnél tréfából elismételte a pap szavait, amelyek a szembetegeket haragra lobbantották, a többieket viszont kacagásra ingerelték." 
megtalálták a budai és a visegrádi várakban. Másrészről, a mai Olaszországot csak turistaként ismerő magyarok számára mindig hihetetlennek tűnik az az állítás, amiről a Rómában és Firenzében a téli időszakban dolgozó magyar kutatók mindig panaszkodnak: annyira kevés helyen lehet fázni, mint a nagy olasz könyvtárak 5-6 méteres belmagasságú, ezért befüthetetlen termeiben. Nem beszélve arról, hogy Firenzében például az önkormányzati rendelet értelmében este 10 óra után füteni sem lehet. A kortárs olaszok otthonaik hidegségét úgy védik ki, hogy elektromosan füthető takarókat vesznek, nagyjából november elején, amikor az esős és nedves hideg időjárás megérkezik.

A magyarországi hideg és a fütés elviselhetetlensége, mint kifogás, jó szolgálatot tett a híres Ludovico Ariostónak is, aki állítólag ezen az alapon tagadta meg urától, Ippolito d'Este érsektől illetve akkor már egri püspöktől azt, ${ }^{7}$ hogy vele Magyarországra jöjöön. Talán részben a magyarországi időjárás is szerepet játszhatott Ippolito d'Este azon döntésében, hogy az esztergomi érsekséget egy alacsonyabb rangú és jövedelmü, viszont állandó magyarországi jelenlétet nem igénylő püspökségre cserélte, évtizedekkel azelőtt, hogy a Tridentinum kötelezően elöírta volna a főpapoknak az egyházmegyéjükben tartózkodást. ${ }^{8}$

Szintén felmerül a Visino-anekdotában a nyelvtudás kérdése: a magyar udvari emberek közül csak a nyilván itáliai tanulmányokat végzett püspök érti a firenzei nyelvét, a többiek csak a hanglejtésből, és a mondatait kísérő valószínű röhögcséléséből (erre utalhat a „véletlenségből kissé vidám volt” kifejezés) következtettek arra, hogy itt valamilyen, némileg becsmérlő megjegyzés hangozhatott el. Annak kiderítése, hogy az Itáliát járt püspökök

\footnotetext{
${ }^{7}$ Ludovico Ariosto első szatírájában írta le az Ippolito D'Estét magyarországi szolgálatába is követő barátjának, Lodovico da Bagnónak negatív véleményét az „északi” ország klimatikus és életmódbeli viszonyairól, amelyek számára taszítóvá tették a magyarországi utazás lehetőségét. Ludovico ARIOSTO, Szatírák - Satire, ford. SIMON Gyula, Bp., Eötvös József Könyvkiadó, 1996, 10-25.

${ }^{8}$ Ippolito d'Este 1487-ben, alig hétéves korában kapta meg nagybátyjától, Mátyás királytól az esztergomi érseki címet, amelyet 1497-ben hivatalosan is elcserélt Bakócz Tamással az egri püspöki címre.
} 
közül az úriember Brodarics István, ${ }^{9}$ vagy valaki más lehetett-e, a történeti kutatásra váró feladat.

$\mathrm{Az}$ anekdota tanúsága szerint az olasz Visino legalább annyira büszke volt saját hazájára, mint amennyire a magyarok hübriszét a Mátyás-korból megmaradt épített környezet táplálta. Persze magyar viszonylatban óriási változást és teljesítményt jelentettek a Hunyadi Mátyás finanszírozta építkezések, de ha belegondolunk, hogy már a jó százharminc évvel korábbi, Az Albertiek édenkertje címü elbeszélésgyüjteményben is a Giotto Campaniléje a viszonyítási alap More és Berto számára, mielőtt Magyarországra elindulnak, ${ }^{10}$ akkor beláthatjuk, hogy a Vasarinál szereplő firenzei festő és az Itáliát nem ismerő magyar urak egész más müvészeti dimenziókban mozogtak. A magyarokról az is ismert vélemény lehetett a korban, hogy büszkék, és tulajdonukra féltékenyek, beleértve a hozzájuk tartozó asszonyokat is, akiket - a Beatrix királynénak útmutatót író Diomede Carafa szerint ${ }^{11}$ - őrizet nélkül beszélgetni sem engedtek más férfiakkal.

Egy másik novellisztikus jellegü történetben is szerepet kap egy festő és egy magyar király. A velencei származású Sebastiano Erizzo Le sei gironate (Hat nap) címü munkájának tizenegyedik ún. történetéről (avvenimento) van szó. Erizzo kötete a Boccaccio óta szokásos „x-számú ifjú ember összegyűlik egy kellemes helyen, és napokon át történeteket mesélnek egymásnak" sémájára épül ugyan, de hiányzik belőle minden frivolság és könnyedség, csupa erkölcsi épülést szolgáló, exemplum-jellegü elbeszélést tartalmaz. Erizzo művét 1554 körül írhatta, de fikciója szerint 1542-ben Padovában hat külföldi (forestieri) tanuló ifjú jön össze hat estén át egy kis beszélgetésre. ${ }^{12}$ Azonban sem az elbeszélők nevei (pl.: Muzio, Emilio), sem az általuk elmesélt

\footnotetext{
9 Brodarics István kb. 1501-1506 között járt Padova és Bologna egyetemeire, majd 1522-1526 között többször volt követségben Rómában is. KASZA Péter, Egy korszakváltás szemtanúja. Brodarics István pályaképe, Pécs - Bp., Kronosz Kiadó - Magyar Történelmi Társulat, 2015, 26, illetve 52-62.

10 Giovanni Gherardi da Prato, Il Paradiso degli Alberti, a c. di Antonio LANZA, Roma, Salerno, 1975 (I Novellieri Italiani, 10), 71-111, 226-236.

11 Diomede CARAFA, De institutione vivendi. Tanítás az életvezetés szabályairól. Emlékeztető Magyarország felséges királynéjának, ford. LÁZÁR István Dávid és VíGH Éva, szerk. EKLER Péter, Bp., Országos Széchenyi Könyvtár, 2006, 61.

12 Sebastiano ERIZZO, Le sei giornate, a c. di Roberto BRAGANTINI, Roma, Salerno, 1977 (I Novellieri Italiani, 35), 14. A tárgyalt elbeszélés a 111-116. oldalakon.
} 
történetek nem olyanok, amelyeket kifejezetten csak nem olaszok mondhatnának el, mivel azok főként ókori szerzőkből és középkori krónikákból újramondott, ismert esetek. Ez alól talán egyedül a magyar János vajdából lett királyról, és névtelen szolgájáról szóló elbeszélés lehet kivétel, amely a kritikai kiadás szerint orális forrásból került be Erizzo gyüjteményébe, ${ }^{13}$ aki maga is Padovába járt egyetemre. Van azonban egy tisztázásra szoruló probléma, amely tanulságos az olaszoknak a magyar kultúrával kapcsolatban máig élő sztereotípiái szempontjából. Az olasz kritikai kiadás ${ }^{14}$ jegyzetei minden kétség nélkül állítják, hogy a történetben Hunyadi János vajdáról van szó, s fel is mondják tömör életrajzát, törökellenes harcaitól a királlyá lett fiáig, de egyáltalán nem reagálnak arra a tényre, hogy János királyként van megnevezve Erizzo szövegében, és hogy Hunyadi János csak a kormányzóságig vitte. Ennek a lapszusnak a pozitív magyarázata az lehetne, hogy Hunyadi tisztelete olyan mélyen ivódott be az olasz köztudatba a Kapisztrán Szent Jánossal közösen véghezvitt nándorfehérári diadal okán, hogy még hivatásos irodalomtörténészeknek sem fordul meg a fejükben más János vajdát keresni a magyar történelemben. ${ }^{15} \mathrm{~A}$ kiadókat az is félrevezethette, hogy a történetek zöme a régi időkbe, korábbi évszázadokba nyúlik vissza, s ebbe az időintervallumba jobban beleillik Hunyadi János alakja, mint a kortárs Szapolyai Jánosé. Sajnos

\footnotetext{
${ }^{13}$ ERIZZO, i. m., 111, 1. j.

14 ERIZZO, i. m., 112, 3. j.

15 A negatív magyarázat az, hogy nem is kerestek másik János vajdát. Egy kritikai kiadás készítőitől ennél professzionálisabb hozzáállás lenne elvárható ugyan, de nem ez az első eset, hogy a magyar történelem szereplőit olasz irodalomtörténészek más történelmi alakokkal keverik össze. Eneas Silvius Piccolomini Historia de duobus amantibusának jó három évtizedig domináns latin-olasz kétnyelvü kiadásában például (Enea Silvio PICCOLOMINI, Storia di due amanti e Rimedio d'amore, trad. e. introd. di Maria Luisa DOGLIO, con un saggio di Luigi FIRPO, Torino, UTET, 1973, 53, 1. j.) Maria Luisa Doglio azt állítja, hogy a Zsigmondhoz, Ausztria hercegéhez, illetve az ő nevében készült Piccolomini-levelek Luxemburgi Zsigmond császárnak szóltak volna. Sajnos a téves adat öröklődött a neolatin novellairodalom egyik alapvető összefogalaló tanulmányába is. Gabriella AlBANESE, Da Petrarca a Piccolomini: codificazione della novella umanistica = Favole, parabole, istorie: le forme della scrittura novellistica dal Medioevo al Rinascimento. Atti del Convegno di Pisa 26-28 ottobre 1998, Roma, Salerno, 2000, 257-308. itt: 295. Természetesen a levelek címzettje nem az idős császár, hanem az akkor még ifjú Habsburg Zsigmond (1427-1496) volt, akit később maga Piccolomini már II. Pius pápaként regulázott meg rossz magatartásáért azzal, hogy kiátkozta az egyházból.
} 
az olasz kritikai kiadás összeállítói Banfi Florio egy kis közleményét sem ismerhették, amelyben ő a "Zápolya János királyról” szóló novelláról hírt adott, mert az csak magyarul jelent meg, és Banfi semmilyen kommentárt nem füzött a dologhoz. ${ }^{16}$

Erizzo története szerint János király szeme láttára lopja el inasa a feleségétől kapott, kedvenc gyürüjét, de a király semmi rosszra nem gondol, mert azt hiszi, hogy az inas csak el akar hencegni vele valakinek. Amikor azonban napok múlva sem találja a király a helyén a gyürüt, és az inas kérésre sem adja elő, majd pedig úgy tesz, mintha azt valaki más lopta volna el, a történet komolyra fordul. Az inas által megvádolt szerencsétlen festő, akit kínvallatással vesznek rá a hamis vallomásra, csaknem életével fizet az inas hazugságáért - és tegyük hozzá, a király komédiázó kedve miatt is, aki ugyan az inast teszi próbára, de mellékesen megkínoztatja az általa is tudottan ártatlan festőt. Évszázadokra vagyunk még a felvilágosult olasz szerző, Cesare Beccaria érvelésétől, aki Európában az egyik első gondolkodóként emelte fel a szavát a kínvallatás ellen, így a festő felesleges szenvedése, vagy a kínzás igazságtalansága szót sem érdemel a történetben. Ennek ellenére az elbeszélő a király bölcsességét dicsőíti, aki „csak” lelkileg kínozza meg hűtlen inasát, az életét meghagyja, mielőtt elbocsátaná szolgálatából. Az inas távozásakor egy régi, be nem váltott fogadalmára hivatkozik, hogy Itáliában fel kell keresnie a loretói kegyhelyet.

A történet olvastán az a benyomásom támadt, mintha a tökéletes udvari viselkedésről kapnánk itt egy példabeszédet: minden a látszat (apparenza) fenntartásáról szól, hiszen a dolgok igazi okát senki előtt nem tárja fel sem a király, sem az inas; az inasnak parancsra el kell játszania az elbocsátásért való könyörgést, a király pedig szertartásosan engedi el őt szolgálatából, és még meg is könnyezi kedves szolgája elvesztését. A király azon tette, hogy mementóként inasának ajándékozza a bünjelet, vagyis az ellopott gyűrüt, a király szavai ellenére mindkettőjüket örökre emlékeztetni fogja az elkövetett bünre: az inast állandó jelenlétével, a királyt pedig hiányával. Jóllehet az elbeszélő a király őszinte bánatát és megbocsátását hangsúlyozza az inassal szemben, számomra a gyưrü átadása az inas megbélyegzésével egyenértékű; a király hangsúlyozott nagylelkűségében ugyan valóban nem fosztja meg inasát a fizikai lététől, de megfosztja az

${ }^{16}$ BANFI Florio, Olasz novella Zápolya János királyról, Erdélyi Múzeum, 1931, 404-405. 
életének keretet adó helyzetétől és arra kényszeríti, hogy magának ne bocsáthasson meg soha. ${ }^{17}$

Mielőtt a történet valós gyökereit keresni kezdenénk, érdemes felhívni a figyelmet arra is, hogy Sebastiano Erizzo múvének eredetileg volt egy másik magyar vonatkozású része is. Attilának, a magyarok[!] ${ }^{18}$ királyának születéséről (Del nascimento di Attila, re degli Unni) szóló darabját a szerző szándékosan nem a történet (avvenimento), hanem a novella (itt kb. 'híresztelés') szóval jellemezte. Erizzo elbeszélése a Velencében már évszázadok óta létező, és minduntalan újramesélt, volgare nyelven sokszor ki is nyomtatott történetet mondja el: e szerint Ostrubaldo magyar király (Osdrubaldo, re di Ungheria) leánya, akit egy toronyba zárnak, jobb híján egy fehér kutyával összegabalyodva szüli meg a kutyafejű gyermeket, miután hozzáment egy magyar grófhoz, és sikerült elhitetnie a férjével, hogy a fogantatás közben egy kutyára gondolt, ezért lett a gyermek kutyafejü- és fülü. A történet ismertsége ellenére a Tridentinum ellenreformációs szellemében a cenzor azonban kivetette a nyomtatásból ezt a novellát, ${ }^{19} \mathrm{~s}$ azt csak 1796-ban jelentette meg London hamis nyomdahellyel Livornóban egy

17 Mint Petneházi Gábor kollégám felhívta rá a figyelmem, Szapolyai János brutalitás iránti hajlama is jól ismert volt a kortársak szemében. Taurinus István Stauromachia, avagy a keresztesek paraszti háborúja címü eposzában például részletesen leírja, hogy a vajda, azaz Szapolyai parancsára hogyan szaggatják szét saját katonái a tüzes királyi jelvényekkel megkínzott Dózsa György testét. „Nádvesszővel üzött szolgái csapatja körötte / táncot járt szilajon, s vad urát gúnyolta: királyát. / Majd, fenyegetve kivont tőrrel, hogy jelt ad a vajda, / rontva reá rágják, szaggatják puszta fogukkal; / tépik a szétroncsolt tagokat, nyeldesve, amit már megrágtak, s azután kezdik szürcsölni kiomló / vérét is - nyomorult szolgák! - eltelve a hússal. / Íly hóhér-lakomát kínál, iszonyú terítéket, / rettenetes lével telehintve az ördögi asztal!" TAURINUS István, Stauromachia, avagy a keresztesek paraszti háborúja = Janus Pannonius, Magyaroroszági humanisták, s. a. r. KLANICZAY Tibor, ford. MURAKÖZY Gyula, Bp., Szépirodalmi Könyvkiadó, 279, 164-172. skk.

18 ERIZZO, i. m., 311-333. Itáliában Attila a X. századtól kezdve a magyarok királyaként szerepelt a köztudatban, ennek a hun-magyar azonosításnak évszázados továbbéléséről tanúskodik Erizzo szövege is. Vö. CSUKOVITS Enikő, Magyarországról és a magyarokról Nyugat-Európa magyar-képe a középkorban, Bp., MTA BTK Történettudományi Intézet, 2015, 68.

${ }^{19}$ ERIZZO, i. m., 311. Felhívom rá a figyelmet, hogy Bozóky Edina más tekintetben hasznos kötetének magyar kiadásában hibásan az szerepel, hogy az Erizzo-féle novella Le sei giornate „részeként látott napvilágot.” BOZÓKY Edina, Attila - A hun király és legendái, Bp., Kossuth Kiadó, 2015, 134. 
Riccardo Bancker nevü nyomdász. ${ }^{20}$ Az ilyen időtávlatból már nem rekonstruálható, hogy a szerzői szándék látott-e összefüggést a két, magyarokhoz kapcsolódó történet között, vagy Erizzo csupán anyanyelvi erudícióját akarta bizonyítani azzal, hogy egy régen ismert velencei mesét írt meg újra, retorikailag jobban felékesítve, a latin humanizmusnak ekkorra már a népnyelvü írásokban is átvett követelményei szerint. ${ }^{21}$

Visszatérve az állítólag Szapolyai János királyról és szolgájáról szóló történetre, megpróbálhatunk némi történeti alapot adni az eseményeknek. Szapolyainak volt felesége, még ha a korban idősnek számított is a király, amikor 1539-ben elvette a 20 esztendős Jagelló Izabellát. Egy ilyen királyi házasságkötés kölcsönös ajándékozásokkal járt, ${ }^{22} \mathrm{~s}$ Izabella jegyajándékai között ékszerek, gyürűk is szerepelhettek, hiszen a házasságkötésnek a gyưrüváltás is hagyományos része volt. ${ }^{23}$ Ha Erizzo a saját egyetemi évei alatt hallott valami történetet a magyar királyról, akkor az az 1540-es években

${ }^{20}$ ERIZZO, i. m., 332.

${ }^{21}$ Például a megesett, egyébként névtelen királylány érvelése láthatóan sokban támaszkodik Leonardo Bruni latin nyelven megszólaló, de az eredetileg boccacciói hősnő (Decameron IV, 5) Ghismonda figurájának a beszédére, aki önnön szexualitásának jogosságát védelmezi apja, Tancredi király előtt. ERIZZO, i. m., 313, 1. j.

22 Például Hunyadi Mátyás és Aragóniai Beatrix esküvőjén a pár első találkozásakor egy drágakövekkel és aranygyürüvel ékesített koszorú cserélt gazdát. A dologról azonban másképp számol be Berzeviczy Albertnek a királynéről írt monográfiája, illetve egy ismeretlen német forrás. Berzeviczy szerint Beatrix küldte előre Bánffy Miklóst a koszorúval a királyhoz, akit nagy gyönyörüséggel töltött el az ajándék. „Nicola Bánffy, l'inviato della fidanzata, giunse primo e presentò al re, da parte di Beatrice, un magnifico mazzo dal quale pendea un prezioso anello ornato di un diamante di grande valore. Mattia fu commosso ricevendo il dono della fidanzata, ma la sua attentione fu tosto stornata dall'arrivo di colei che lo aveva mandato." Alberto BERZEVICZY, Beatrice d'Aragona, a c. di Rodolfo MoscA, Milano, Edizioni Corbaccio, 1931, 77. Az ismeretlen német forrás magyar fordítása pedig így számol be a történtekről: „A királynő a király előtt fele úton, a szőnyegeken térdre borult. A király azonnal hozzásietett, kezét nyújtotta, felemelte és gyöngéden magához ölelte. Majd fejére helyezett egy drágakövekkel díszített puszpángkoszorút, amelyen aranygyürüje függött." BORSA Béla, Ismeretlen, egykorú német leírás Mátyás és Beatrix házasságáról, Pécs, 1940, 22.

23 Szapolyai János egy értékes nyakláncot, egy díszes tükröt és egy aranygyürüt küldött követei útján Izabellának a krakkói per procuram esküvőre. Izabella egy gyémántos gyürűje máig fennmaradt, az Andrássyak gyüjteményéből külföldi magántulajdonba került. Ewa LETKIEWICZ, The Jewels of Queen Isabella of Hungary, Folia Historica, 24(1996), 197. 
történt, de később is találhatott embert, aki magyar dolgokról meséljen Padovában. ${ }^{24}$ Valami igazság abban is van, hogy Szapolyai foglalkoztatott müvészeket: kőfaragókat biztosan, de valószínúleg festőket is alkalmazott, s erről Itáliában is tudhattak. Mint Ritoókné Szalay Ágnes kimutatta, Hunyadi Jánosnak a gyulafehérvári székesegyházban álló tumbáját Szapolyai János parancsára állíttatta fel Statileo János püspök 1533-ban. ${ }^{25}$ Ritoókné Szalay Ágnes hívta fel a figyelmemet arra az adatra, hogy Istvánffy Miklós történetíró is tud a votív oltárról, amelyet Szapolyai Tarnówban emeltetett, amikor lehetősége volt visszatérni Magyarországra: „Hallván János király, az övéinek ily alkalmatos győzedelmét, semmit sem várakozván, minekutána Tarnovaynak az szállástartásnak $s$ jótéteményének ajándékait felette igen megköszönte, és hogy soha arról el nem feledkeznék, magát azzal ajánlotta, s az tarnovai szentegyházban egy igen szépen megékesített oltárt építtetvén, számkivetésének emlékezetit hadta volna." ${ }^{26}$ A szóban forgó oltár mára már sajnos elpusztult. Szapolyai királyi udvarának anyagi kultúrájáról keveset tudunk, ${ }^{27}$ de valószínúleg ő is olasz, vagy legalábbis Itáliában tanult mesterekkel dolgoztatott, ahogy előtte II. Ulászló és főként Mátyás király korában maguk az uralkodók, illetve a fópapok is tették. ${ }^{28}$ Érdekes adat viszont, hogy ahogyan a novellában az inas Loretóba készül, úgy 1532-ben a már pápai kiközösítéssel sújtott Szapolyai János gyóntatóját, a ferences Hardi

${ }^{24}$ Az ilyenfajta mesélgetésre későbbi példa, amikor a Padovában tanuló Kornis György egy 1592. március 13-án kelt levelében számol be apjának, Kornis Farkasnak az ő köreiben Zsigmond császárról elhangzott történetről. VERESS Endre, Matricula et acta Hungarorum in universitatibus Italiae studentium, Bp., Stephaneum, 1915-1917, 243.

25 RitoóKnÉ SzAlay Ágnes, Hunyadi János († 1456) gyulafehérvári síremlékének dombormüvei = Történelem-kép. Szemelvények múlt és müvészet kapcsolatáról Magyarországon - A Magyar Nemzeti Galériában 2000. március 17-szeptember 24. között rendezett kiállítás katalógusa, szerk. MIKÓ Árpád, SINKÓ Katalin, Bp., Magyar Nemzeti Galéria, 2000, 297-298.

${ }^{26}$ Istvánffy Miklós Históriája Tállyai Pál XVII. századi fordításában, I/1., s. a. r. BENITS Péter, Bp., Balassi, 2001, 263.

27 KIRÁly Péter, A zene János király udvarában, Magyar Zene, 1991, 3-4 sz., 284-88., 386-391.

28 A gyakran csak nevükről ismert alkotók magyarországi szerepéről a magyar Jagellók idejében 1. SPENKNER Enikő, MIKÓ Árpád, La successione del trono: gli Jagelloni all'ombra dei turchi = Mattia Corvino e Firenze: Arte e Umanesimo alla corte del re di Ungheria, Firenze, Giunti, 2013, 324-329. Illetve a Mátyás udvarában is dolgozó német-firenzei Alexander Formoserről: Louis A. WALDMAN, Alexander Formoser: un pittore straniero, mediatore di cultura fiorentina = Mattia Corvino e Firenze..., i. m., 300-303. 
Gellértet Loretóba és az apostolok sírjához küldte zarándoklatra, s ezzel az ürüggyel tudta bejuttatni követét a pápához, aki hivatalosan nem érintkezett kiátkozás alatt álló személyekkel. ${ }^{29}$ Sebastiano Erizzo novellájának tehát vannak olyan elemei, amelyekre találhatunk párhuzamokat Szapolyai János uralkodásának eddig feltárt történetében, még ha ezek az adatok egészen más időrendet mutatnak is, mint a novellában szereplő események, s jelenleg csupán gyenge kapocsként szolgálnak is a valóság és a novella fikciós tere között. A jövő kutatásának feladata, hogy a Szapolyaiak és Itália kapcsolatairól többet megtudjanak, hiszen Barlay Ö. Szabolcs tanulmányain kívül $^{30}$ alig kutatott kérdés a Szapolyai-Jagelló család irodalmi és/vagy fikciós megjelenése a magyar, olasz vagy a lengyel irodalomban.

A fent bemutatott két rövid, itáliai eredetü elbeszélés és a rajtuk keresztül felidézett további, a magyarokkal kapcsolatos anekdotikus jellegü történetek egy kis bepillantást engedtek abba a folyamatba, ahogyan a sokszor csak egy szűk elit által ismert, vagy többszörös áttétel útján Itáliába jutott információk kerek történetekké álltak össze. A folyamat eredményeként kialakult elbeszéléseket talán egy olasz közmondással jellemezhetnénk legjobban: se non è vero, ben trovato - ha nem is igaz, jól ki van találva.

\section{Sebastiano Erizzo novellája Szapolyai János királyról}

Jánostól, Magyarország királyától egy inasa ellop egy gyürüt. Az inas egy festőt vádol meg, aki a kínvallatás hatására bevallja a lopást, és halálra ítéltetik; a halálbüntetés alól, mint ártatlant, felmentik, és az inas bevallja a lopást, a király pedig elbocsátja és neki ajándékozza ugyanazt a gyürüt.

XI. Történet

Miután Camillo úr ilyen szép történet elmondásával megtette a kötelességét, és miután Agilulf lágy és hüséges szeretetét, és kitartó lelkületét többen dicsérték, úgy tetszett Emilio úrnak, hogy Muzio úr legyen a következő mesélő, aki pedig ilyenformán kezdett beszélni: Hogy mennyire szorítja a lelket a mások iránti szeretet, és hogy milyen megfontolásokra vezeti ez az

\footnotetext{
29 NEMES Gábor, Folytonosság vagy újrakezdés? Magyarország és az apostoli Szentszék kapcsolatainak alakulása Mohács előtt és után = Egyházi társadalom a Magyar Királyságban a 16. században, szerk. VARGA Szabolcs, VÉRTESI Lázár, Pécs, Pécsi Hittudományi Főiskola, 2017, 123-124.

30 BARLAY Ö. Szabolcs, Romon virág. Fejezetek a Mohács utáni reneszánszról, Bp., Széphalom Könyvmühely, 1986, ${ }^{1} 2001 .{ }^{2}$
} 
embereket, azt könnyen megérthetjük Agilulf nagylelkű tettéből, aki inkább akart az urát ért bosszúban vele együtt halni, mint túlélve ôt, megsiratni. ${ }^{31}$ De nekem, mivel most a szolgákra terelődött a szó, szándékomban áll megmutatni nektek egy király jóságos és türelmes természetét, amelyről egy szolgától elszenvedett sértésben tett tanúbizonyságot; amelyet, ha összehasonlítunk Robertónak $^{32}$ az önmérsékletével, amelyet fia halálának megbosszulásában mutatott, annál nagyobb csodálkozásra és dicséretre méltónak fogjátok tartani, minél nagyobb dolog az, hogy egy főember és úr, akinek teljes felhatalmazása van rá, hogy bármely akaratát érvényesítse alárendeltje felett, egy alárendeltjétől megsértve saját erényéből megtartóztatja magát ettől; úgy, hogy ő, aki ezt a szabadságot másoktól kapta, és szerénységből nem használja, épp ezáltal hagyja, hogy e szabadság megtegye a hatását, pedig ő is jól tudja, hogy az, aki ezt a szabadságot neki adományozta, sem többet, sem kevesebbet nem tenne a helyében. Azontúl világos lesz számotokra, hogy ő nemcsak hogy nem üldözte gyülölettel és bosszúval az ellene vétkezőt, hanem veleszületett jóindulata miatt elég nagylelküen, és azzal ellentétesen, amit az megérdemelt volna, meg is jutalmazta. S nincs kétségem felöle, hogy kedves lesz ezt meghallgatnotok.

Emlékszem, hogy egyszer azt hallottam mesélni, hogy amikor János vajda volt Magyarország királya, volt neki egy inasa, akire legkedvesebb és legtitkosabb dolgait is rábízta. És mivel az inas mindenhova bejáratos volt a háztartásban, egy nap a király egy deszkafal nyílásán át meglátta őt, amint abban a kicsiny szobában volt, ahol a király dolgait őrizték, és ott az inas kinyitott egy szekrényt, és kivett belőle egy hatalmas értékü gyürüt, amelyik, mivel a feleségétől kapta ajándékba, különösen kedves volt a királynak. Namármost, hogy a király látta az inast ilyen titokban elvenni a gyürüt, azt gondolta, hogy az valami nőnek vagy valamelyik barátjának akarja megmutatni, és ezért hallgatott róla és kedves volt hozzá.

De aztán, hogy sok nap eltelt, a királynak eszébe jutott a gyürü, és ő maga ment a szekrényhez, hogy megnézze, esetleg az inas visszatette-e már; de nem találta ott, és hallgatott. Aztán este, vetkőzés közben mondta az inasnak, hogy másnap azt a gyürüt akarja az ujjára húzni, és ha ő elfeledkeznék róla, hogy kérje, akkor az inas emlékezzen rá, és adja oda neki. Eltelt az a nap és a

\footnotetext{
31 Visszautalás a közvetlen megelőző, tehát a második nap X. történetére.

32 Visszautalás az első nap IV. történetére.
} 
következő is, és az inas nem figyelmeztette a királyt, és máshogy se adta oda neki a gyürüt; erre a király újra ugyanazt mondta neki, de ő akkor se tett másként. Elég zaklatottan harmadjára is szólt neki, de az inast még ez se hatotta meg egy jottányit se.

Így hát egy reggel a király mosolyogva mondta neki:

- Menj most, mert eszembe jutott, és hozd ide a gyürüt.

Erre az inas a szekrényhez ment, ahonnan kis idő múlva teljesen félve és megzavarodva jött vissza, és azt mondta, hogy a gyưrü nincs ott, és hogy Őfelsége emlékezzen csak jól vissza rá, hogy nem vette-e fel korábban. Mikor a király azt válaszolta neki, hogy nem, akkor úgy tett, mintha elmenne, hogy jobban utánanézzen; és mindent teljesen fölforgatva a végén azt találta mondani, hogy senki más nem lophatta el, csak az a festő, aki azokban a napokban azt a kicsiny szobát kifestette. És, bár a király figyelmeztette, hogy ne vádoljon senkit, anélkül, hogy tudná, hogy történt, az inas még jobban erősködött, hogy biztosan a festő volt. Erre pedig a király egyetértésével az inas elfogatta és börtönbe záratta a festőt, és a dolognak megfelelően eljárva meg is kínoztatta. A kínvallatásra a nyomorult kénytelen volt bevallani, hogy ő volt, és amiatt halálra ítélték, hogy azt mondta, hogy elküldte Itáliába a gyürüt eladásra; ami nem volt igaz, de a kínzás hatására ezt kellett mondania.

Akkor a király magához hívatta az inast, és azt mondta neki, hogy nem viselné el, ha az az ártatlan szenvedne büntetést a lopásért, amelyet ő követett el, és hogy az inas, nem pedig a festő lopta el azt, és felfedte előtte a napot, az órát és a módot, amikor látta ôt elvenni a gyürüt. Amint ezt meghallotta az inas, a király lábai elé vetette magát, és elkezdett bocsánatért esedezni. De a király így szólt hozzá: Ami minket illet, mi megbocsátunk neked, de másfelől az igazság nem engedi, hogy megbocsátást nyerj. Úgy illik, hogy elégtételt vegyünk az ártatlanon, és viszahelyezzük az őt megillető helyre. Ezért te úgy fogsz tenni, mintha megtaláltad volna a gyürüt, hogy öt ártatlannak ismerje el mindenki, és hogy elismerjék, hogy amit önmagáról mondott, azt a kínzás kényszere alatt kellett mondania. Így tehát az inas úgy cselekdett, ahogy a király elrendelte, és a festőt azonnal szabadon engedték.

De a király titokban magához hívatta az inast, és ezt mondta neki: Akármilyen nagy volt is a te bünöd, amit elkövettél ellenünk, a festő ellen, az igazság és Isten ellen, ettől függetlenül, mivel ezek közül az Isten a legnagyobb, és ő nem bocsát meg, legalább mi megbocsátunk neked. De szentül meg 
vagyunk győződve róla, hogy te sosem bocsátanál meg nekünk: ezért hát intézd úgy, hogy útnak indulsz és elmész innen. A bölcs király ezeken a szavakon azt értette, hogy az, aki a bünt elköveti, saját lelkiismerete miatt mindig rossz érzéssel lesz az iránt és rossz szándékkal az ellen, aki ellen elkövette. Így tehát megparancsolta neki, hogy nyilvánosan kérjen tőle engedélyt a távozásra, és hogy a király minél jobban tagadja tôle, az inas annál kitartóbban könyörögjön érte. Úgy történt tehát, hogy néhány nappal később, miután a király megvacsorázott, az inas a lábai elé vetette magát, és azt mondta neki, hogy az anyja emlékeztette egy fogadalmára, hogy elmegy a Miasszonyunkhoz Loretóba, Itáliába, s ő eldöntötte, hogy nem halogatja tovább, és a király, csodálkozást színlelve azt válaszolta neki, hogy a hosszú idő alatt, amíg az ő szolgálatában állt, a szolgálatáért cserébe csak kérnie kellett volna a fizetséget (mint ahogy a lelkében éppen ezt akart kérni), ha el akart menni; annál is inkább, mivel ő már nem reméli, hogy még egyszer egy olyan készséges és kedves szolgát találjon, mint amilyen ő volt neki. Tehát egyik és a másik részről is sok szó hangzott el, és az inas köszönetét fejezte ki a királynak a tőle telhető legnagyobb mértékben, és azt mondta, hogy muszáj elmennie. Így végül a király az inasnak nyilvánosan osztott sok kegy után könnyezni látszott; aztán szemeit az ujjára fordítva, amelyen azt a nagyon kedves gyürüt viselte, jó néhányszor körbeforgatta és levette, és az inasnak adta, azt mondva: Mivel eldöntötted, hogy elmész, hogy a kötelességnek megfelelően többet törődj Istennel, mint másokkal, nézz rá, hogyan tudsz minket is részesíteni az irántad való isteni jóindulatból és kegyből, és könyörögj, hogy minden megadassék neked; és mivel nekünk, ahogy te is tudod, nincs kedvesebb dolog a világon ennél a gyưrünél, mi neked ajándékozzuk azt, a te emlékezetedre és a mi feledésünkre; és többet nem mondott. Ezekkel a szavakkal megérttette az inasával, hogy ő magát fosztotta meg a gyürütől, hogy ennek révén a király elfeledhesse, hogy a miatt a gyürü miatt veszített el egy olyan kedves szolgát, mint amilyen az inas volt neki, hiszen az bünt követett el ellene; ennek révén az inas pedig mindig emlékezetében tarthassa a hibáját, és hogy azután jobb emberként éljen, mint ahogyan királyával élt; valóban királyi és nagylelkü tett, amely másokat kétsgében hagyott afelől, vajon a királynak melyik erénye volt inkább dicséretre és csodálatra méltó: az az önmérséklet-e, amellyel az inas igazságtalanságát kezelte, vagy az a jóindulat-e, amelyet olyan iránt mutatott, akire büne miatt a törvény szerint a bosszú várt volna. 